\title{
Food Processing Methods towards Reduction of Antinutritional Factors in Chickpea
}

\author{
Anindita Roy*, Sanhita Ghosh and S. Kundagrami \\ Department of Genetics and Plant Breeding, Institute of Agricultural Science, University of \\ Calcutta, Kolkata-700019, India \\ *Corresponding author
}

Keywords

Chickpea, Antinutritional factors, Food processing methods, IVPD and IVSD

Article Info

Accepted: 04 December 2018 Available Online: 10 January 2019

\section{A B S T R A C T}

Chickpea (Cicer arietinum L.), commonly known as garbanzo beans, are one of the most commonly consumed legumes in all over the world. Being one of the most nutritional elements of the human diet, chickpea contained various antinutritional compounds, including trypsin inhibitors, chymotrypsin inhibitors, phytic acid, tannin, condensed tannin and alpha amylase inhibitors which hampered the utilization of the nutrients by people. These antinutritional factors also hinder the in-vitro digestibility of both protein and starch. Hence, it is very necessary to eliminate these compounds and improving the in-vitro digestibility of both protein and starch so that these chickpea germplasms can be used as an alternative high valuable crop for the farmers and helps to provide health promoting food products in future. Food processing methods such as soaking, germination and roasting were quite popular to minimize these toxic substances. Based on the results, germination reduced only alpha amylase inhibitors (51.97\%-53.53\%) whereas roasting lowered trypsin inhibitors (62.16\%-74.62\%), chymotrypsin inhibitors (47.25\%-56.02\%), phytic acid (39.45\%-46.66\%), tannin (50.94\% -61.01\%) and condensed tannin (44.45\%$47.95 \%)$. The improvement in in-vitro digestibility of both protein $(3.63 \%-7.20 \%)$ and starch $(20.29 \%-21.42 \%)$ were observed by roasting treatment. Considering all the processing methods attempted in the present study, roasting was the best method in improving the in vitro digestibility of protein and starch through lowering the antinutritional factors.

\section{Introduction}

Chickpeas play an integral role in human diet on account of their incredible nutritive value for billions of people especially in developing and under developing nations where majority of population is vegetarian either due to their choice or economic reasons (Sood et al., 2002). However, the consumption of chickpeas are restricted due to the presence of various anti-nutritional compounds such as trypsin inhibitor, chymotrypsin inhibitors, alpha amylase inhibitors, phytic acid, tannin and condensed tannin (Wang et al., 2010) which retard the nutrients availability. Trypsin and chymotrypsin inhibitors have the capacity to bind with hydrolytic enzymes, such as trypsin and chymotrypsin and impeding their 
activity, while phytic acid is found to mitigate the availability of minerals from chickpeas by forming insoluble complexes with polyvalent cations such as $\mathrm{Cu}, \mathrm{Zn}, \mathrm{Co}, \mathrm{Mn}, \mathrm{Fe}$ and $\mathrm{Ca}$ (Harland and Oberleas, 1987).

Tannins and condensed tannins have the affinity to bind with protein hinder the protein digestibility and amino acid availability (Srivastava and Srivastava, 2003). The alpha amylase inhibitors inhibit the activity of amylase enzyme and impaired the starch digestion and absorption. Therefore, it is very essential to reduce these antinutritional factors and subsequently improving the nutritional quality of chickpeas to enhance their potential as human food.

With the aim of ameliorating the nutritive value of chickpeas, some domestic food processing methods have been developed to significantly increase the bioavailability of nutrients. The domestic food processing methods viz., soaking, germination and roasting are widely accepted to utilize the maximum nutritional value of chickpeas before consumption. The objective of this present research was to investigate the impact of these domestic processing methods on reducing the level of antinutritional factors and consequently improving the in vitro digestibility of both protein and starch.

\section{Materials and Methods}

\section{Sample collection}

Five chickpea germplasms were taken from NBPGR, Berhampore and some of them were local collection. The seeds were hand-sorted to remove all the dirt and foreign materials, then stored in polyethylene bags in the refrigerator $\left(-4^{0} \mathrm{C}\right)$ until used.

\section{Samples preparation}

Raw and dry chickpeas were taken as control.

\section{Processing methods}

\section{Soaking}

All the chickpea seeds were soaked at room temperature for 9 hour in plain water. The seed to solution ratio was 1: $3(\mathrm{w} / \mathrm{v})$. The soaking water was drained off, and rinsed twice in distilled water.

\section{Roasting}

The chickpea seeds were roasted using hot airoven at temperature at $160{ }^{\circ} \mathrm{C}$ for $20 \mathrm{~min}$. The chickpea seeds were turned after every $5 \mathrm{~min}$ until all the portions of the seeds were light brown in colour.

\section{Germination}

All the chickpea seeds were soaked in plain water $(1: 3, \mathrm{w} / \mathrm{v})$ for overnight at room temperature $\left(22-23^{\circ} \mathrm{C}\right)$. After that, the soaked seeds were placed on moist filter paper in petridishes and then were placed in a dark incubator at $24-28^{\circ} \mathrm{C}$ for $24 \mathrm{~h}$ germination.

After all the processing methods, the treated chickpea germplasms were oven dried at $55^{\circ} \mathrm{C}$ till constant weight and grinded until to pass through $5 \mathrm{~mm}$ sieve and preserved in deep freezer $\left(-20^{\circ} \mathrm{c}\right)$ for further analysis.

\section{Analysis of antinutritional factors}

Trypsin inhibitor activity levels in chickpea were done according to the method of Kakade et al., (1974) as modified by Hammerstrand et al., (1981) using BAPNA (N-a-Benzoyl-DLArginine p-nitroanilide hydrochloride) as a substrate. The method of Mulimani and Rudrappa (1993) was followed to estimate $\alpha$ amylase inhibitory activity (AIA) in chickpea seed. Chymotrypsin inhibitor was done according to the method of Makkar et al., (2007). The phytic acid was measured by following the method of Kaur et al., (2014). 
Total tannins were determined as described in AOAC (1990). Condensed tannin was estimated according to the method of $\mathrm{Xu}$ and Chang 2007 using the acidified vanillin reagent. IVPD of chickpea seeds were determined using the method described by Salgo' et al., 1984 and modified by Uppal and Bains (2012). In vitro starch digestibility was assessed using the method given by Singh et al., 1982 and modified by Uppal and Bains (2012). These entire assays were done in triplicates with slight modifications.

\section{Statistical analysis}

All the statistical analyses were done using SPSS Program version 20. The results were expressed as mean \pm S.D. Duncan multiple range test (DMRT) was used to assess the statistical significant differences among several samples at $\mathrm{P} \leq 0.001$.

\section{Results and Discussion}

\section{Trypsin inhibitor}

The trypsin inhibitor content in chickpea germplasms varied from 11.82-13.08 $\mathrm{mg} / \mathrm{g}$. The influences of food processing methods on trypsin inhibitor content are presented in Table 1. The highest concentration of trypsin inhibitor was found in Annigeri $(13.08 \mathrm{mg} / \mathrm{g}$ ) and lowest concentration was found in Virat $(11.82 \mathrm{mg} / \mathrm{g})$. The treatments of soaking in plain water caused significant $6.57 \%-8.17 \%$ reduction in different antinutritional factors which varied with the germplasms. Mubarak (2005) reported similar findings in mungbean seeds. This diminution indicated the solubilization of some level of trypsin inhibitor into water during soaking while germination reduced $27.13 \%-34.46 \%$ trypsin inhibitor significantly in comparison with raw. El-Adawy (2002) reported similar results. Germination activated trypsinase enzyme which would help to reduce its content. Roasting had been shown to be very effective in reducing $62.16 \%-74.62 \%$ trypsin inhibitor content than other processing methods. Sharma et al., (2016) found similar reports in chickpea germplasms. Reduction of trypsin inhibitor during roasting might be due to the heat sensitive nature of trypsin inhibitor which becomes inactivated at high temperature (Vidal-Valverde et al., 1994).

\section{Phytic acid}

The amount of phytic acid in chickpea germplasms varied widely ranging from $11.38-11.59 \mathrm{mg} / \mathrm{g}$. The impacts of food processing on phytic acid content are presented in Table 2. Annigeri $(11.59 \mathrm{mg} / \mathrm{g})$ exhibited the highest concentration of phytic acid while BGM408 (11.38 mg/g) was the lowest. Soaking decreased the phytic acid content ranged from $15.19 \%$ - $17.78 \%$. Soaking instigated the leaching of phytate ions into soaking water under the influence of concentration gradient and reduced the phytic acid content in chickpea germplasms. Better reduction in phytic acid content has been observed during germination ranged from $25.87 \%-32.84 \%$. Similar results have been found by El-Adawy (2002). Germination induced the reduction of phytic acid content which might be ascribed to the de novo synthesis of phytase enzyme which helped to degrade the content (Afify et al., 2011; Luo et al., 2009b).The treatment of roasting (39.45\% - 46.66\%) significantly proved to be the most effective than any other methods. These results were in accordance with Sharma et al., (2016) The decreased in phytic acid content have been attributed to heat labile nature of phytic acid which was degraded at high temperature.

\section{Tannin}

The tannin makes the chickpea slightly bitter in taste which varied from $4.94 \mathrm{mg}$ - 
$5.30 \mathrm{mg} / \mathrm{g}$. Effects of food processing methods on tannin contents in chickpea are presented in Table 3. Annigeri $(5.30 \mathrm{mg} / \mathrm{g})$ recorded the highest tannin content and lowest concentration was found in IC268966 (4.94 $\mathrm{mg} / \mathrm{g}$ ). However, soaking reduced $16.90 \%$ 23.28\% tannin content which might be ascribed to hydrolysis nature of the water soluble tannin which might be leached out into the water (Vijayakumari et al., 2007). Consequently, germination reduced the tannin contents $(22.66 \%-35.22 \%)$ but it had no significant effect. El-Adawy (2002) found similar results. The reduction in tannins contents were due to the presence of tannin in outer coat of the seed which gets ruptured during germination. Roasting had the maximum significant effect on lowering the tannin contents $(50.94 \%-61.01 \%)$. Similar reports have been found by Sharma et al., (2016) in chickpea germplasms. The decrease in tannin content during roasting might have been attributed to the activation of tannase which instigated the degradation of tannin content in chickpea germplasms.

\section{Condensed tannin}

The condensed tannin concentration in chickpea germplasms varied from 1504.33$1618.00 \mu \mathrm{gCAE} / \mathrm{g}$. The influences of food processing on condensed tannins are presented in Table 4. The germplasm namely BGM408 was seen to attain the maximum condensed tannin content i.e. $1618.00 \mu \mathrm{gCAE} / \mathrm{g}$ and the minimum was Virat (1504.33 $\mu \mathrm{gCAE} / \mathrm{g})$. However, the impact of soaking was minimal but it caused $6.21 \%-6.88 \%$ reduction in condensed tannin content. The reduction was might be due to the soluble property of this antinutrient which leached out into soaking medium through diffusion. Germination reduced condensed tannin content ranging from $32.51 \%-36.42 \%$ which might be due to enzymatic hydrolysis by polyphenolase enzyme. Roasting significantly proved to be more effective than both soaking and germination (44.45\% - 47.95\%). Bulbula and Urga (2018) also reported a similar reduction in condensed tannin content after application of roasting. The reduction of condensed tannin content during roasting might be due to heat labile properties of condensed tannin which degraded at elevated temperature.

\section{Alpha-amylase inhibitor}

The concentration of alpha amylase inhibitor in chickpea germplasms varied from 51.50$52.08 \mathrm{U}($ Units $) / \mathrm{g}$. Effects of food processing on alpha amylase inhibitor content in chickpea are presented in Table 5. IC268966 exhibited the highest amount of alpha-amylase inhibitor $(52.08 \mathrm{U} / \mathrm{g})$ while Virat was the lowest $51.50 \mathrm{U} / \mathrm{g}$. Soaking significantly reduced $9.66 \%-10.37 \%$ alpha amylase inhibitor content in chickpea germplasms which might be ascribed to the solubilization of alpha amylase inhibitor into soaking medium. Germination was the most effective treatment in reducing alpha amylase inhibitor content significantly $(51.97 \%-53.53 \%)$. Similar results of reduction had been found by Mulimani and Rudrappa 1993. The decrease in alpha amylase inhibitor content could be due to the activation of alpha amylase enzyme. During roasting the decrease in alpha amylase inhibitor content varied from $25.31 \%$ $28.80 \%$. Reduction of alpha amylase inhibitor content during roasting might be due to heat labile property of alpha amylase inhibitor.

\section{Chymotrypsin inhibitor}

Raw chickpea germplasms contained chymotrypsin inhibitor content varied from 13.03-13.10 CIU/mg. The impacts of food processing on chymotrypsin inhibitor content in chickpea are presented in Table 6. BGM408 (13.10 CIU/mg) exhibited maximum amount of chymotrypsin inhibitor content while CUML4 (13.03 CIU/mg) recorded minimum. 
During soaking, the decrease in chymotrypsin inhibitor content ranged from 3.13\% - 3.90\%. The reduction of chymotrypsin inhibitor content might be due to low molecular weight of chymotrypsin inhibitor which leached out into the water. The reduction of chymotrypsin inhibitor content in the chickpea germplasms during germination was moderate $6.79 \%$ $15.96 \%$ which was ascribed to the decomposition of chymotrypsin inhibitors by active proteinase enzyme. The treatment of roasting $(47.25 \%-56.02 \%)$ has been proved to be more effective than any other processing methods. Reduction of chymotrypsin inhibitor during roasting might be due to heat sensitive nature of chymotrypsin inhibitor.

\section{IVPD}

Raw chickpea contained IVPD varying from $61.95 \%-63.67 \%$ respectively. The influences of food processing on IVPD in chickpea germplasms are shown in Table 7. BGM408 exhibited highest IVPD content i.e. $63.67 \%$ while Annigeri recorded lowest i.e. $61.95 \%$. Soaking caused a little improvement in IVPD content ranging from $2.62 \%-3.43 \%$. During soaking the improvement in the in vitro digestibility of protein might be attributed to leaching out of all the antinutritional factors which was known to bind with protein to form insoluble complexes. However, the percent increase in IVPD content during germination was $3.92 \%-5.97 \%$. The activation of endogenous proteolytic enzymes hydrolyzed the protein-polyphenol complex which helped in the improvement of IVPD content in the chickpea germplasms. This result was in accordance with El-Adawy (2002). Roasting was significantly proved to be more effective than other processing methods.

Table.1 Effects of food processing methods on trypsin inhibitor $(\mathrm{mg} / \mathrm{g})$ content in chickpea germplasms

\begin{tabular}{|l|l|l|l|l|}
\hline Variety & Raw & Soaking & Germination & Roasting \\
\hline Virat & $11.82 \pm 0.05 \mathrm{a}$ & $10.88 \pm 0.05 \mathbf{a}$ & $7.85 \pm 0.06 \mathrm{~b}$ & $3.00 \pm 0.03 \mathrm{a}$ \\
\hline Annigeri & $13.08 \pm 0.05 \mathrm{~b}$ & $12.22 \pm 0.05 \mathbf{c}$ & $9.40 \pm 0.07 \mathrm{~d}$ & $4.95 \pm 0.03 \mathrm{~d}$ \\
\hline IC268966 & $11.84 \pm 0.05 \mathrm{a}$ & $10.93 \pm 0.06 \mathbf{b}$ & $7.76 \pm 0.05 \mathrm{a}$ & $3.07 \pm 0.03 \mathrm{ab}$ \\
\hline BGM 408 & $13.05 \pm 0.02 \mathrm{~b}$ & $12.26 \pm 0.05 \mathbf{c}$ & $9.51 \pm 0.06 \mathrm{e}$ & $4.87 \pm 0.03 \mathrm{c}$ \\
\hline CUML4 & $11.87 \pm 0.07 \mathrm{a}$ & $10.90 \pm 0.05 \mathbf{b}$ & $7.93 \pm 0.05 \mathrm{c}$ & $3.15 \pm 0.03 \mathrm{~b}$ \\
\hline
\end{tabular}

Note: Mean values of each column with different letters in the same row followed by different superscript letter (ae) are significantly different at $\mathrm{P} \leq 0.001$

Table.2 Effects of food processing methods on phytic acid $(\mathrm{mg} / \mathrm{g})$ content in chickpea germplasms

\begin{tabular}{|l|l|l|l|l|}
\hline Variety & Raw & Soaking & Germination & Roasting \\
\hline Virat & $11.51 \pm 0.05 \mathrm{~b}$ & $9.74 \pm 0.05 \mathbf{c}$ & $7.73 \pm 0.06 \mathrm{a}$ & $6.14 \pm 0.04 \mathrm{a}$ \\
\hline Annigeri & $11.59 \pm 0.06 \mathrm{~b}$ & $9.83 \pm 0.05 \mathbf{d}$ & $7.87 \pm 0.06 \mathrm{ab}$ & $6.38 \pm 0.05 \mathrm{~b}$ \\
\hline IC268966 & $11.56 \pm 0.05 \mathrm{~b}$ & $9.79 \pm 0.05 \mathbf{c}$ & $8.57 \pm 0.06 \mathrm{~d}$ & $7.00 \pm 0.05 \mathrm{e}$ \\
\hline BGM 408 & $11.38 \pm 0.05 \mathrm{a}$ & $9.56 \pm 0.05 \mathbf{b}$ & $8.37 \pm 0.09 \mathrm{~b}$ & $6.85 \pm 0.04 \mathrm{c}$ \\
\hline CUML4 & $11.53 \pm 0.05 \mathrm{~b}$ & $9.48 \pm 0.05 \mathbf{a}$ & $8.49 \pm 0.06 \mathrm{c}$ & $6.92 \pm 0.05 \mathrm{~d}$ \\
\hline
\end{tabular}

Note: Mean values of each column with different letters in the same row followed by different superscript letter (ae) are significantly different at $\mathrm{P} \leq 0.001$ 
Table.3 Effects of food processing methods on tannin $(\mathrm{mg} / \mathrm{g})$ content in chickpea germpalsms

\begin{tabular}{|l|l|l|l|l|}
\hline Variety & Raw & Soaking & Germination & Roasting \\
\hline Virat & $5.03 \pm 0.05 \mathrm{~b}$ & $4.18 \pm 0.05 \mathbf{b}$ & $3.89 \pm 0.05 \mathrm{c}$ & $2.26 \pm 0.06 \mathrm{c}$ \\
\hline Annigeri & $5.30 \pm 0.05 \mathrm{c}$ & $4.26 \pm 0.05 \mathbf{c}$ & $3.67 \pm 0.07 \mathrm{bc}$ & $2.66 \pm 0.05 \mathrm{~d}$ \\
\hline IC268966 & $4.94 \pm 0.05 \mathrm{a}$ & $3.79 \pm 0.05 \mathrm{a}$ & $3.20 \pm 0.06 \mathrm{a}$ & $2.14 \pm 0.04 \mathrm{~b}$ \\
\hline BGM 408 & $5.12 \pm 0.07 \mathrm{~b}$ & $4.21 \pm 0.05 \mathbf{c}$ & $3.85 \pm 0.05 \mathrm{c}$ & $2.18 \pm 0.05 \mathrm{~b}$ \\
\hline CUML4 & $5.13 \pm 0.05 \mathrm{~b}$ & $4.12 \pm 0.05 \mathbf{b}$ & $3.57 \pm 0.06 \mathrm{~b}$ & $2.00 \pm 0.05 \mathrm{a}$ \\
\hline
\end{tabular}

Note: Mean values of each column with different letters in the same row followed by different superscript letter (ad) are significantly different at $\mathrm{P} \leq 0.001$

Table.4 Effects of food processing methods on condensed tannin $(\mu \mathrm{gCAE} / \mathrm{g})$ content in chickpea germpalsms

\begin{tabular}{|l|l|l|l|l|}
\hline Variety & Raw & Soaking & Germination & Roasting \\
\hline Virat & $1504.33 \pm 0.05 \mathrm{a}$ & $1408.52 \pm 0.05 \mathrm{a}$ & $1003.11 \pm 0.05 \mathrm{~b}$ & $803.11 \pm 0.05 \mathrm{~b}$ \\
\hline Annigeri & $1507.00 \pm 0.04 \mathrm{a}$ & $1412.57 \pm 0.04 \mathbf{a b}$ & $1017.10 \pm 0.05 \mathrm{c}$ & $837.10 \pm 0.05 \mathrm{~cd}$ \\
\hline IC268966 & $1511.67 \pm 0.03 \mathrm{bc}$ & $1414.50 \pm 0.05 \mathbf{a b}$ & $961.07 \pm 0.06 \mathrm{a}$ & $791.08 \pm 0.04 \mathrm{a}$ \\
\hline BGM 408 & $1618.00 \pm 0.05 \mathrm{~d}$ & $1506.66 \pm 0.06 \mathbf{c}$ & $1074.08 \pm 0.05 \mathrm{e}$ & $874.08 \pm 0.06 \mathrm{~d}$ \\
\hline CUML4 & $1585.00 \pm 0.06 \mathrm{c}$ & $1486.65 \pm 0.05 \mathbf{b}$ & $1044.07 \pm 0.04 \mathrm{~d}$ & $825.06 \pm 0.04 \mathrm{c}$ \\
\hline
\end{tabular}

Note: Mean values of each column with different letters in the same row followed by different superscript letter (ae) are significantly different at $\mathrm{P} \leq 0.001$

Table.5 Effects of food processing methods on alpha amylase inhibitor (U/g) content in chickpea germpalsms

\begin{tabular}{|l|l|l|l|l|}
\hline Variety & Raw & Soaking & Germination & Roasting \\
\hline Virat & $51.50 \pm 0.05 \mathrm{a}$ & $46.32 \pm 0.05 \mathrm{a}$ & $24.09 \pm 0.06 \mathrm{a}$ & $38.32 \pm 0.03 \mathrm{~b}$ \\
\hline Annigeri & $51.53 \pm 0.05 \mathrm{a}$ & $46.49 \pm 0.05 \mathrm{~b}$ & $24.75 \pm 0.06 \mathrm{e}$ & $38.49 \pm 0.03 \mathrm{~d}$ \\
\hline IC268966 & $52.08 \pm 0.05 \mathrm{c}$ & $47.05 \pm 0.05 \mathrm{c}$ & $24.20 \pm 0.06 \mathrm{c}$ & $37.08 \pm 0.04 \mathrm{a}$ \\
\hline BGM 408 & $51.78 \pm 0.05 \mathrm{~b}$ & $46.39 \pm 0.05 \mathrm{a}$ & $24.52 \pm 0.07 \mathrm{~d}$ & $38.07 \pm 0.03 \mathrm{c}$ \\
\hline CUML4 & $51.80 \pm 0.05 \mathrm{~b}$ & $46.43 \pm 0.05 \mathrm{~b}$ & $24.14 \pm 0.07 \mathrm{~b}$ & $37.30 \pm 0.04 \mathrm{~b}$ \\
\hline
\end{tabular}

Note: Mean values of each column with different letters in the same row followed by different superscript letter (ae) are significantly different at $\mathrm{P} \leq 0.001$

Table.6 Effects of food processing methods on chymotrypsin inhibitor (CIU/mg) content in chickpea germpalsms

\begin{tabular}{|l|l|l|l|l|}
\hline Variety & Raw & Soaking & Germination & Roasting \\
\hline Virat & $13.05 \pm 0.05 \mathrm{~b}$ & $12.64 \pm 0.05 \mathbf{b}$ & $12.05 \pm 0.05 \mathrm{~b}$ & $6.75 \pm 0.03 \mathrm{~b}$ \\
\hline Annigeri & $13.09 \pm 0.05 \mathrm{c}$ & $12.68 \pm 0.06 \mathbf{b}$ & $12.09 \pm 0.05 \mathrm{~b}$ & $6.70 \pm 0.02 \mathrm{~b}$ \\
\hline IC268966 & $13.08 \pm 0.05 \mathrm{c}$ & $12.57 \pm 0.05 \mathbf{a}$ & $12.16 \pm 0.06 \mathrm{bc}$ & $6.83 \pm 0.03 \mathrm{c}$ \\
\hline BGM 408 & $13.10 \pm 0.05 \mathrm{~d}$ & $12.72 \pm 0.05 \mathbf{c}$ & $12.21 \pm 0.05 \mathrm{c}$ & $6.91 \pm 0.03 \mathrm{~d}$ \\
\hline CUML4 & $13.03 \pm 0.05 \mathrm{a}$ & $12.54 \pm 0.04 \mathrm{a}$ & $10.95 \pm 0.05 \mathrm{a}$ & $5.73 \pm 0.03 \mathrm{a}$ \\
\hline
\end{tabular}

Note: Mean values of each column with different letters in the same row followed by different superscript letter (ad) are significantly different at $\mathrm{P} \leq 0.001$ 
Table.7 Effects of food processing methods on IVPD (\%) content in chickpea germpalsms

\begin{tabular}{|l|l|l|l|l|}
\hline Variety & Raw & Soaking & Germination & Roasting \\
\hline Virat & $62.85 \pm 0.04 \mathrm{~d}$ & $64.85 \pm 0.03 \mathrm{~d}$ & $65.57 \pm 0.06 \mathrm{~b}$ & $66.75 \pm 0.04 \mathrm{~d}$ \\
\hline Annigeri & $61.95 \pm 0.04 \mathrm{a}$ & $63.57 \pm 0.05 \mathrm{a}$ & $64.38 \pm 0.06 \mathrm{a}$ & $65.06 \pm 0.04 \mathrm{a}$ \\
\hline IC268966 & $62.25 \pm 0.04 \mathrm{~b}$ & $64.22 \pm 0.04 \mathrm{~b}$ & $65.76 \pm 0.06 \mathrm{bc}$ & $66.12 \pm 0.03 \mathrm{c}$ \\
\hline BGM 408 & $63.67 \pm 0.03 \mathrm{e}$ & $65.56 \pm 0.02 \mathrm{e}$ & $66.37 \pm 0.05 \mathrm{~d}$ & $65.98 \pm 0.03 \mathrm{~b}$ \\
\hline CUML4 & $62.35 \pm 0.04 \mathrm{c}$ & $64.49 \pm 0.03 \mathrm{c}$ & $66.07 \pm 0.05 \mathrm{c}$ & $66.84 \pm 0.03 \mathrm{e}$ \\
\hline
\end{tabular}

Note: Mean values of each column with different letters in the same row followed by different superscript letter (ae) are significantly different at $\mathrm{P} \leq 0.001$

Table.8 Effects of food processing methods on IVSD (\%) content in chickpea germpalsms

\begin{tabular}{|l|l|l|l|l|}
\hline Variety & Raw & Soaking & Germination & Roasting \\
\hline Virat & $70.51 \pm 0.05 \mathrm{~b}$ & $73.93 \pm 0.05 \mathrm{~b}$ & $85.05 \pm 0.06 \mathrm{~b}$ & $85.15 \pm 0.06 \mathrm{~b}$ \\
\hline Annigeri & $70.14 \pm 0.04 \mathrm{a}$ & $73.98 \pm 0.05 \mathrm{c}$ & $84.45 \pm 0.06 \mathrm{a}$ & $84.50 \pm 0.06 \mathrm{a}$ \\
\hline IC268966 & $70.87 \pm 0.05 \mathrm{c}$ & $74.42 \pm 0.07 \mathrm{~d}$ & $85.19 \pm 0.07 \mathrm{bc}$ & $85.25 \pm 0.05 \mathrm{c}$ \\
\hline BGM 408 & $70.71 \pm 0.05 \mathrm{bc}$ & $73.90 \pm 0.05 \mathrm{a}$ & $85.31 \pm 0.05 \mathrm{c}$ & $85.45 \pm 0.05 \mathrm{~d}$ \\
\hline CUML4 & $70.76 \pm 0.04 \mathrm{bc}$ & $74.89 \pm 0.06 \mathrm{~cd}$ & $85.72 \pm 0.05 \mathrm{~d}$ & $85.92 \pm 0.05 \mathrm{e}$ \\
\hline
\end{tabular}

Note: Mean values of each column with different letters in the same row followed by different superscript letter (ae) are significantly different at $\mathrm{P} \leq 0.001$

Fig.1 Effects of domestic processing methods on different antinutritional factors in chickpea germplasm CUML4

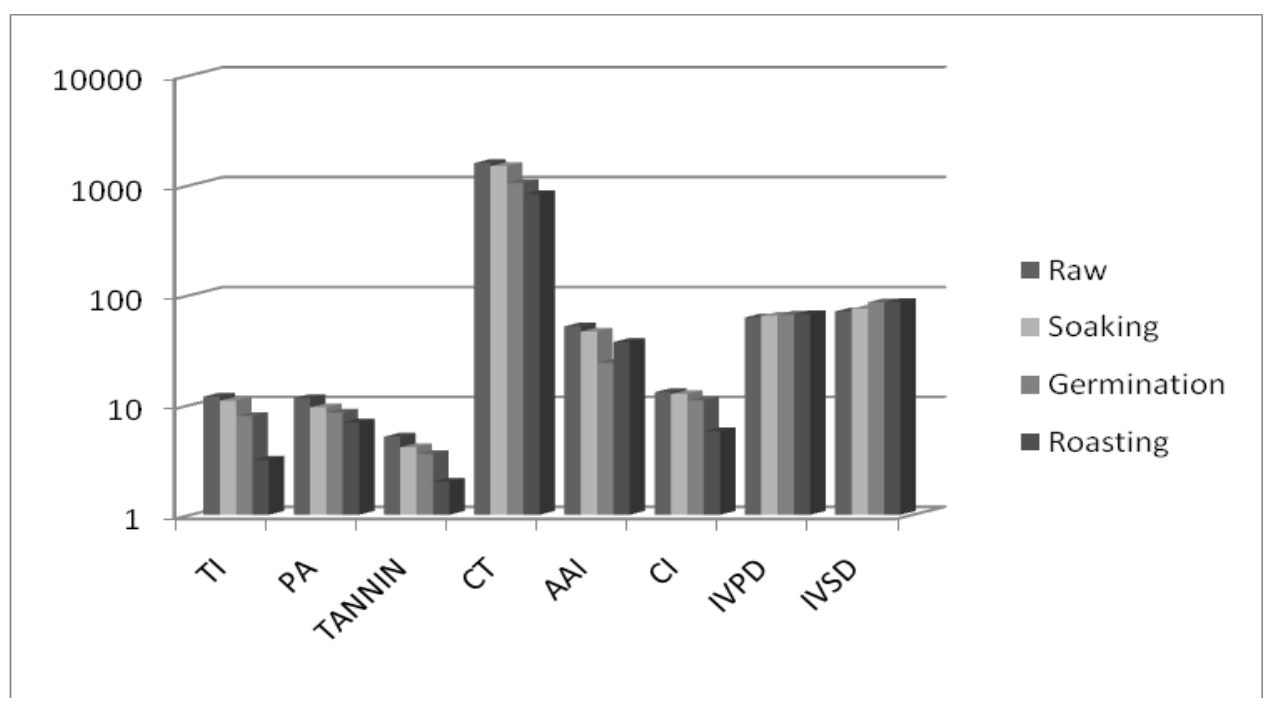

Uruj and Puttaraj (1994) reported similar results in chickpea germplasms. The processing method of roasting improved IVPD content $3.63 \%-7.20 \%$ which might be due to the inactivation of proteinanceous antinutritional factors at elevated temperature.

\section{IVSD}

IVSD content of chickpea germplasms varied from $70.14 \%$ - $70.87 \%$. The impacts of soaking and thermal treatments on IVSD in chickpea germplasms are shown in Table 8. 
The germplasm namely IC268966 was seen to attain the maximum condensed tannin content i.e. $70.87 \%$ and the minimum was Annigeri $(70.14 \%)$. Although soaking had no significant effect on IVSD content, it improved $4.51 \%$ - 5.84\% which might be attributed to the inactivation of heat labile inhibitors. Ordinarily, germination improved the IVSD content $20.21 \%-21.14 \%$. Similar result of improvement was found by Uppal and Bains (2012).

The activation of amylase and phosphorylase enzyme during germination instigated the degradation of starch into smaller fragments and improved the starch digestibility. The treatment of roasting significantly improved IVSD content ranging from $20.29 \%-21.42 \%$ than others. This result was in accordance with Simsek et al., (2015). The degradation of starch at high temperature improved the invitro starch digestibility during roasting.

Among the five chickpea germplasms, CUML4 was the topmost germplasm which displayed the significant improvement in invitro digestibility of protein and starch by lowering maximum amount of different antinutritional factors (Figure 1). Hence, CUML4 could be used as a nutritious germplasm in the global market in future.

In conclusion, soaking contributes a very little role in lowering the antinutritional factors while germination holds a good potential for improving the in vitro digestibility of both protein and starch. The present research ascertains roasting as an effective practice for upgrading the nutritional qualities of chickpea germplasms through lowering the antinutritional factors. Consumption of such processed chickpeas could serve as an excellent source which would help to combat the food and nutritional security from people of developing and under developing nations.

\section{References}

Afify, A.E.M.M.R., El-Beltagi, H.S., Abd, ElSalam, S.M., and Omran, A.A.,2011, Bioavailability of iron, zinc, phytate and phytase activity during soaking and germination of white sorghum varieties. PLoS One, 6: 25512.

AOAC. 1990. Official methods of analysis, 15th edn. Washington, D.C.: Association of Official Analytical Chemists.

Bulbula, D., and Urga, K. 2018. Study on the effect of traditional processing methods on nutritional composition and anti nutritional factors in chickpea (Cicer arietinum). Cogent Food \& Agriculture. 4: 1422370.

El-Adawy, T. A. 2002. Nutritional composition and antinutritional factors of chickpeas (Cicer arietinum L.) undergoing different cooking methods and germination. Plant Foods for Human Nutrition. 57: 83-97.

Hammerstrand, G. E., Black, L. T. and Glover, J. D. 1981. Trypsin inhibitor in soy products: modification of standard analytical procedures. Cereal Chemistry. 15: 215-218.

Harland, B. F., and Oberleas, D. 1987. Phytate in foods. World Rev Nutr Diet. 52:235259.

Kakade, M.L., Rackis, J. J., McGhee, J. E., and Puski, G. 1974. Determination of trypsin inhibitor activity of soy products: a collaborative analysis and improved procedure. Cereal Chemistry. 51: 376-382.

Kaur, S., Kaur, S., Gupta, A. K., and Kaur, N. and Javed, M. 2014. Biochemical and nutritional characterization of chickpea (Cicer arietinum) genotypes. Indian $J$ Agric Sci., 84: 479-486

Luo, Y.W., Xie, W.H., Xie, C.Y., Li, Y., and Gu, Z.X. 2009b. Impact of soaking and phytase treatments on phytic acid, calcium, iron and zinc in faba bean fractions. International Journal of Food 
Science and Technology, 44, 25902597.

Makkar, H.P.S., Siddhuraju P., and Becker, K. 2007. Methods in molecular biology: plant secondary metabolite. Humana Press Inc, Totowa.

Mubarak, A.E. 2005. Nutritional composition and antinutritional factors of mung bean seeds (Phaseolus aureus) as affected by some home traditional processes. Food Chemistry. 89: 489- 495.

Mulimani, V.H. and Rudrappa, G.1993. Effect of heat treatment and germination on alpha amylase inhibitor activity in chickpeas (Cicer arietinum L) 1993. Plant Foods for Human Nutrition, 46:133-137.

Prodanov, M., Sierra, I., and Vidal-Valverde, C. 2004. Influence of soaking and cooking on the thiamine, riboflavin and niacin contents of legumes. Food Chem. 84 (2):271-277.

Salgo', A., Granzler, K., and Jecsai, J.1984. Simple enzymatic methods for predication of plant protein digestibility. Proc Int Assoc Cereal Chem Symp ed La'sztity R, Hidve'gi M Akade'miai Kiado',Budapest, pp. 311-321.

Sharma, S., Singh, A., Sharma, U., Kumar, R., and Yadav, N. 2016. Effect of thermal processing on anti nutritional factors and in vitro bioavailability of minerals in desi and kabuli cultivars of chick pea grown in North India. LR-3708: 1-8.

Simsek, S., Herken, E. N., and OvandoMartinez, M. 2015. Chemical composition, nutritional value and in vitro starch digestibility of roasted chickpeas. J Sci Food Agric. 96: 28962905.
Singh, U., Kherdekor, M.S., and Jambunathan, R. 1982. Studies on desi and kabuli chickpea cultivars the levels of amylase inhibitors, level of oligosaccharides and in vitro starch digestibility. J Food Sci, 47: $510-512$

Sood, M., Malhotra, S. R., and Sood, B. C. 2002. Effect of processing and cooking on proximate composition of chickpea (Cicer arietinum) varieties. J Food Sci Technol. 39:69-71.

Srivastava, R. P., and Srivastava, G. K. 2003. Nutritional value of pulses. Indian $J$ Agric Biochem. 16(2):57-65

Uppal, V. and Bains, K. 2012. Effect of germination periods and hydrothermal treatments on in vitro protein and starch digestibility of germinated legumes. $J$ Food Sci Technol. 49(2): 184-191.

Uruj, A., and Puttaraj, S. 1994. Effect of processing on starch digestibility in some legumes - An in vitro study. Die Nahrung. 38 (1): 38-46

Vidal-Valverde, C., Frias, J., Estrella, I., Gorospe, M. J., Ruiz, R. and Bacon, J. 1994. Effect of processing on some antinutritional factors of lentils. J Agric Food Chem 42(10): 2291-2295.

Wang, N., Hatcher, D.W., Tyler, R.T., Toews, R. and Gawalko, E. J. 2010. Effect of cooking on the composition of beans (Phaseolus vulgaris L.) and chickpeas (Cicer arietinum L.). Food Research International, 43: 589-594.

$\mathrm{Xu}$, B.J., and Chang, S.K.C. 2007. A comparative study on phenolic profiles and antioxidant activities of legumes as affected by extraction solvents. J Food Sci, 72: 159-166.

\section{How to cite this article:}

Anindita Roy, Sanhita Ghosh and Kundagrami, S. 2019. Food Processing Methods towards Reduction of Antinutritional Factors in Chickpea. Int.J.Curr.Microbiol.App.Sci. 8(01): 424-432. doi: https://doi.org/10.20546/ijcmas.2019.801.044 